\title{
Economics
}

\section{Towards Sustainable Development: Role of the Housing Fund Program for the Poor in Bangladesh}

\author{
Sadia Islam \\ Dhaka School of Economics, Constituent Institution, University of Dhaka, Dhaka, Bangladesh \\ Email address: \\ sadia_manoar@yahoo.com

\section{To cite this article:} \\ Sadia Islam. Towards Sustainable Development: Role of the Housing Fund Program for the Poor in Bangladesh. Economics. \\ Vol. 9, No. 3, 2020, pp. 66-72. doi: 10.11648/j.eco.20200903.13
}

Received: September 8, 2020; Accepted: September 23, 2020; Published: October 12, 2020

\begin{abstract}
The word home is associated with the place where people can rest their heads at the end of the day. But in a developing country like Bangladesh, there are still many people who are homeless. Although there are different types of home loans available for the homeless. However, this study focused on the Grihayan Tahobil Program which was set up to provide housing loans to the extremely poor who have very limited incomes, who live in urban slums or who have become homeless as a result of river erosion. The main goal of this study is to evaluate how the social economic development issues change because of the government housing loan program (Grihayan Tahobil) in the Bangladesh to help ensure sustainable development goals. This study mainly based on primary and secondary data and primary data were collected from sample respondents through a structured questionnaire via face to face interview. Data on perception of household head on the changes in social status, health status of the respondent household head, difference in the indicator of women empowerment, food standard, children education and access to clean water and sanitation were collected through this survey. This study used systematic random sampling techniques. A total of 5 NGOs from all over the Dhaka division has been selected randomly. With the help of these $5 \mathrm{NGOs,} 190$ beneficiary households and 70 non beneficiary households have selected systematically from the five different districts for the survey. All of the findings indicate that after having an access of housing fund loan for a house, it is likely to report changes in their social status. The study finds that 90 percent of the program beneficiary households have enjoyed a positive change in their social status. The results also indicate that a new house not only improves the socioeconomic condition of the program beneficiary household but also it is helping Bangladesh moving towards to sustainable development.
\end{abstract}

Keywords: Housing, Fund, Socioeconomic, Program, Beneficiary, Sustainable, Development

\section{Introduction}

Housing is a basic life sustaining needs or items which not only provides shelter to the people but also plays a very essential role on the people of the dwellers in terms of health safety, security, level of living standard and human dignity [1]. Recently, housing is treated as an essential necessity in some countries which is related to human right [2]. Like other countries hosing is also a constituent of social development in Bangladesh. Without ensuring house for each and every family social development is quite impossible. Bangladesh is a densely populated country in the world. The current population of Bangladesh is more than 16.42 corers. The population density of Bangladesh is 1265 per $\mathrm{km}^{2} .20 .5$ percent of people live below in poverty line and 4 percent people are living in extreme poverty [3]. Due to this over population still now there are many people who don't have their shelters.

Bangladesh is a middle income country and also a shining star of the Millennium Development Goals. Now Bangladesh is moving towards to the journey of achieving sustainable development. Bangladesh is doing very well in many sectors, according to the Social Progress Index-2018; Bangladesh has most opportunity of improving on the shelter component. To the fulfillment of social progress of Bangladesh we need to ensure housing facilities for all people. Shelter is a component of basic human need, so everybody has the right to meet their basic needs. For ensuring housing facilities Bangladesh has a lot of the institutional infrastructure for housing fund. Besides the government-subsidized or stateowned housing finance the Bangladesh House Building 
Finance Corporation (BHBFC) other sectors of financing are also available now in Bangladesh. A large number of NGOs (Grameen Bank, Proshika, Brac, Asa, etc.), commercial banks, employee loans and informal means are providing housing loans in the Bangladesh [4].

Apart from this all institutions in Fiscal Year 1997-98, the Government of the People's Republic of Bangladesh (GoB) created a housing fund, namely "Grihayan Tohobil" for the sake of giving low-cost housing to the homeless poor people especially women workers, homeless families due to natural calamities and river erosion, poor people in urban slum areas of the country Bangladesh. "Grihayan Tohobil" was established through the allocation of 50 crore taka only from the budget in FY 1997-98. Later the budget allocation was increased to Tk 298 crore. The money received has now risen to around Tk 400 crore through investment in a revolving system.

The project Grihayan Tohobil was the brainchild of the Honorable Prime Minister Sheikh Hasina and is being administered by the Prime Minister's office. To ensure social development and basic human needs this project is providing housing fund to alleviate the crisis of home of the poor people of the Bangladesh. Especially, this project focuses on the homeless people due to river erosion and poor female workers. In addition to housing construction, the fund has adopted work plans for housing workers, especially female garment workers, female workers working in EPZ handicrafts under BEPZA, dormitories to accommodate single or family, disadvantaged tea workers. The main objective of implementing all these activities is to help the present government achieve the Sustainable Development Goals (SDGs) [5].

The goals and objectives of the Housing Fund are closely linked to some of the important goals of sustainable development. The key to sustainable development is to include everyone in the mainstream of development. The main goal of sustainable development is to ensure that everyone gets their fair share. The agenda for the sustainable development is everybody is included; nobody is excluded [6]. One of the goals of the Housing Fund is to provide quality housing for the underprivileged sections of the society. In addition, provision of safe water and sanitary latrines for the beneficiaries of housing fund, inclusion of income generating activities, improvement of socioeconomic status and provision of social security, raising awareness on health, education and environment, increase in family and society status and to make people aware of housing construction by protecting natural reservoirs and agricultural lands are the significant aims and objectives of the Grihayan Tahobil. In other words, every goal and objective of the Grihayan Tahobil will assist the Government of Bangladesh in implementing the SDGs.

Sustainable development is a process which invoking human freedom, human dignity, human rights, equality, inclusiveness and equity. So for assuring sustainable development, we need to ensure development; which is socially acceptable and environmentally durable economic growth, including the human being at the centre of the stage [7]. This project works for extremely poor people with a very low rate of interest. For ensuring sustainable development, we need to confirm an inclusive development. Therefore, giving loans to the extremely poor people and trying to provide them mainstream facilities is essential for achieving sustainable development goals. The NGOs implementing the housing loan program borrow from this fund at a simple interest rate of only 1.5 per cent and 5.50 per cent in Parliament disburse housing loans to the beneficiaries for a maximum period of three to ten years. By 2019, 62,125 houses have been constructed by taking loans from Grihayan Tohobil. As a result, 410,625 people (as 5 members per family) have been benefited from this project. At the beginning of the day, a large loan of $\mathrm{Tk}$ 20,000 was given, which has been gradually increased to Tk 1, 30,000 . A total of 616 NGOs listed with the Grihayan Tahobil, 350 are currently implementing regular loan activities in 404 upazilas in 64 districts of the country [5]. So this Grihayan Tahobil project is working in 64 districts of Bangladesh for ensuring sustainable development. For effective implementation of sustainable development goals, a very essential need for moving forwards successfully in human welfare development through education, health services, food security, women empowerment, the reduction of inequality and poverty eradication.

The main goal of this study is to evaluate how the social economic development issues change because of the government housing loan program (Grihayan Tahobil) in the Bangladesh to help ensure sustainable development goals.

\section{Literature Review}

Housing fund plays an essential role to change socioeconomic status of people by providing them new and less expensive house. The access of housing fund is very important for overall economic development moreover for uplifting the socio-economic position of household's [8]. Provide housing facilities is one of the vital responsibilities of the govt. Hock-Smit identify that a main difficulties to promote the housing conditions for middle and lower income households is state indifference to find out accessible housing finance [9]. Some of the studies found that to gripe the housing demand for the next upcoming 20 years, Bangladesh have to make 4 million houses in a year [10]. A study done by the World Bank in 2010 showed that, in Bangladesh there is a shortage of 5 million houses annually [2]. But In year 2019, World Bank mentioned that Bangladesh must have to make at list 8.5 million houses in the upcoming next five years to control the countries extreme housing demand [11]. Rahman did a study related to the housing of the urban poor of Bangladesh. Mainly his study explores the role NGOs and its limitations in case of housing sectors in Bangladesh [12].

One of the research works has been done by the Bangladesh Institute of Development Studies (BIDS) on the evaluation of the activities of Grihayan Tahobil in 2018. BIDS evaluate the activities of Grihayan Tahobil every elaborately. They collected data from 48 districts and 1700 beneficiary households were surveyed by their study. They find that this housing fund is doing very well and 
contributing enough to its beneficiary households [13].

There are several studies analyzing the impacts of housing finance on socio-economic development. In literature, there are different approaches, some analyze the impact of the housing fund on socio-economic sectors, and some analyze the relationship between economic growth and housing fund. Other types of studies analyze the different types of housing loans and their facilities, some of them also analyze SWOT of the housing loan and so on. But this study aims to find out a very special case, focuses on a housing fund which is created by the Government of the People's Republic of Bangladesh (GoB) namely "Grihayan Tohobil" and wants to explore how this housing fund imposes its impacts on socioeconomic development on its beneficiary households to ensure sustainable development goals.

There are some observation and research gaps identified from the literature review which are -

a) Housing is an essential element for human and housing fund plays an important role for developing countries.

b) There are different types of housing fund facilities available in Bangladesh they are numbers of NGOs (Grameen Bank, Proshika, Brac, Asa etc.), government loans, commercial banks, employee loans, informal means are providing housing loans in the Bangladesh.

c) Existing literature suggested that, to find out the real socio economic impact of a program it is one of the best ways to compare the beneficiaries with non beneficiaries.

d) Most of the study uses primary data for identifying the benefits of housing funds.

e) There is a knowledge gap on the social economic development issues change because of the government housing loan program (Grihayan Tahobil) in the Bangladesh for achieving sustainable development goals.

\section{Methodology}

This work mainly based on primary data but to collect information related to the Grihayan Tahobil project secondary data was also used. Secondary data were collected from different website especially from the project website. Primary data were collected from sample respondents through a structured questionnaire via face to face interview. Data on perception of household head on the changes in social status, health status of the respondent household head, difference in the indicator of women empowerment, food standard and children's education and so on were collected through this survey.

\subsection{Study Area and Sample Size}

A sample survey has been conducted for the study. The survey covers Dhaka division of Bangladesh among the division a total of 190 beneficiary respondent households and 70 non beneficiary households were surveyed. Dhaka division is selected based on the fact that Dhaka is the capital of Bangladesh. The respondents were above 18 years old and mainly the head of the families. Existing literature suggested that, to find out the real socio-economic impact of a program, it is one of the best ways to compare the beneficiaries with non beneficiaries. Therefore, 70 non- beneficiaries households have also been selected from the same divisions, districts, and upazilas.

\subsection{Selection of Sample}

To ensure that the selected sample population represents unbiased this study used systematic random sampling techniques. The housing fund activities are actively related to more than 350 NGOs. The list of the NGOs have been provided on their website and from that list 5 NGOs from all over the Dhaka division has been selected randomly. With the help of these 5 NGOs, 200 beneficiary households have selected systematically from the 5 districts for the survey. But for the incomplete information from the respondents of the households 10 survey answers were rejected among the 200 and finally a total of 190 beneficiary respondent households and 70 non beneficiary households were considered for this study.

Table 1. List of NGOs which helps to get the list of beneficiary household program.

\begin{tabular}{llll}
\hline SI. & Name of the NGO & District & Division \\
\hline 1 & Association of Development for Economic and Social Help & Savar & Dhaka \\
3 & Association for Landless and poor (ALAP) & Gazipur & Dhaka \\
4 & Socio-economic Development Agency (SiDA) & Manikganj & Dhaka \\
5 & United Social Human Advancement Foundation (USHA) & Narayanganj & Dhaka \\
6 & Liya Health Education Development Foundation & Munshiganj & Dhaka \\
\hline
\end{tabular}

Source: http://www.gtbb.gov.bd/mediaroom/enlistedngo.php

Table 2. List of Selected Study Areas and Respondents for the Study.

\begin{tabular}{lllll}
\hline Division & District & Upazila & $\begin{array}{l}\text { Number of Beneficiaries Household } \\
\text { Interviewed }\end{array}$ & $\begin{array}{l}\text { Number of Non-Beneficiaries Household } \\
\text { Interviewed }\end{array}$ \\
\hline \multirow{4}{*}{ Dhaka } & Dhaka & Savar & 48 & 20 \\
& Gazipur & Kapasia & 40 & 15 \\
& Manikganj & Ghior & 32 & 15 \\
& Narayanganj & Rupganj & 35 & 10 \\
Total & Munshiganj & Munshiganj Sadar & 35 & 10 \\
\hline
\end{tabular}

Source: Compiled by the author 


\subsection{Data Analysis Techniques}

This study uses descriptive statistical methods, t-test and frequency distribution method to find out the socio-economic benefits of government housing loan funds. The t-test measures the mean difference of the outcome of interest variable between the beneficiary and non beneficiary households. For this study, the outcome of interest variables are considered-

1. Per capita income and expenditure
2. Food standard

3. Health status

4. Children education

5. Empowerment of women

6. Clean water and sanitation

All of the interest variables are connected with the goals and objectives of the Grihayan Tohobil projects and which are also similar to some of the sustainable development goals.

Table 3. Relations of Variable with Goals and Objectives of the Grihayan Tohobil and Goals of the Sustainable Development.

\begin{tabular}{|c|c|c|}
\hline Interest Variable & Goals and Objectives of the Grihayan Tohobil & Similar Goals of the Sustainable Development \\
\hline $\begin{array}{l}\text { Per capita income and } \\
\text { expenditure }\end{array}$ & $\begin{array}{l}\text { Inclusion of income generating activities for the } \\
\text { beneficiaries of housing fund }\end{array}$ & SDG1 - "End poverty in all its forms everywhere" \\
\hline Food standard & $\begin{array}{l}\text { Provision of social security for the beneficiaries of housing } \\
\text { fund }\end{array}$ & $\begin{array}{l}\text { SDG2-"End hunger, achieve food security and improved nutrition } \\
\text { and promote sustainable agriculture" }\end{array}$ \\
\hline Health status & $\begin{array}{l}\text { raising awareness on health for the beneficiaries of housing } \\
\text { fund }\end{array}$ & SDG3- "Ensure healthy lives and promote wellbeing for all at all" \\
\hline Children education & $\begin{array}{l}\text { Raising awareness on education for the beneficiaries of } \\
\text { housing fund }\end{array}$ & $\begin{array}{l}\text { SDG4- "ensure inclusive and equitable quality education and } \\
\text { promote lifelong learning opportunities for all" }\end{array}$ \\
\hline Empowerment of women & Empowering women by giving loan for creating new house. & SDG5-"Achieve gender equality and empower all women and girls" \\
\hline $\begin{array}{l}\text { Clean water and } \\
\text { sanitation }\end{array}$ & $\begin{array}{l}\text { Provision of safe water and sanitary latrines for the } \\
\text { beneficiaries of housing fund }\end{array}$ & $\begin{array}{l}\text { SGD6- "Ensure availability and sustainable management of water } \\
\text { and sanitation for all" }\end{array}$ \\
\hline
\end{tabular}

Source: Relationship is developed by the author based on the existing information

\section{Findings and Analysis}

To evaluate how the social economic development issues change because of the present government housing loan program for ensuring sustainable development goals this study analyses different steps. Out of respondent 190 from beneficiary and 70 from non beneficiary all are included in the survey to find out the social status of the respondents has changed after getting household loan.

Table 4. Changes in Social Status of the Household Due to Access of the Housing Loan.

\begin{tabular}{llll}
\hline & \multicolumn{3}{l}{ Changes in social status } \\
\cline { 2 - 4 } & Upgraded & Degraded & No change \\
\hline Program (\%) & 90.00 & 2.29 & 7.71 \\
Non-program (\%) & 21.6 & 1.40 & 77.00 \\
\hline
\end{tabular}

Source: Compiled from the Primary Survey

The table 4 presents that 90 percent of the program beneficiary respondents' thing that they have enjoyed and change in social status during the last 3 years as against 21.6 percent of the non program. Where 77 present of the non beneficiary respondents are agreed that there have been no changes in their social status during the last 3 years as against only 7.71 percent of the beneficiary group. So from these results indicate that access to housing fund loan is very significantly changing the social status of the people.

\subsection{Per Capita Income and Expenditure}

The table 5 represents the main differences in income among the household in program and non program group of the Grihayan Tahobil program and this difference in income is statistically significant as confirmed by a significant t-test. The result indicates that per capita income and expenditure among program beneficiary households are higher than non program households. This result also shows that the housing fund project makes enough contribution to fulfill the SDG1 by enhancing the income condition of the program beneficiary households.

Table 5. Differences in income and expenditure among the beneficiary and non beneficiary households.

\begin{tabular}{|c|c|c|c|c|c|c|}
\hline Categories & Program & Non-program & Diff & S. E & t-value & P-value \\
\hline Per capita net income (tk/month) & 3500 & 2872 & 628 & 185 & 3.0 & 0.003 \\
\hline Per-capita expenditure (tk/month) & 3188 & 2519 & 669 & 178 & 3.8 & 0.0001 \\
\hline
\end{tabular}

Source: Compiled from the Primary Survey

\subsection{Food Standard}

Table 6 shows the difference in the indicators of food standard between housing fund program beneficiaries and non beneficiaries. The result shows that number in the program households are more food secured than the non program household. The results indicate that in program households children, pregnant women, lactating mothers and elderly members all are more food secure than the nonprogram households. The low $\mathrm{p}$-value proves the statistical significance of the results and proves that this project is contributing to achieve the SDG2. 
Table 6. Differences in the Indicators of Food Standard between Program Beneficiaries and Non-beneficiaries.

\begin{tabular}{llll}
\hline Indicators of Food Standard & Beneficiary (\%) & Non-Beneficiary (\%) & P-value \\
\hline 1. Family members all get sufficient amount of food & $0.49(0.01)$ & $0.31(0.03)$ & 0.05 \\
2. Children gets their nutritionals food item regularly & $0.40(0.01)$ & $0.27(0.03)$ & 0.05 \\
3. Pregnant women and lactate mothers get special food items & $0.28(0.01)$ & $0.16(0.02)$ & 0.003 \\
4. Elderly member have accesses of proper food nourishment & $0.29(0.01)$ & $0.15(0.02)$ & 0.005 \\
\hline
\end{tabular}

Note: The figure in the parenthesis shows the Standard Error.

Source: Compiled from the Primary Survey

\subsection{Health Status}

This is study represent the health status of number of people in the program households before getting a new house constructed and after getting a new house constructed in terms of frequency the of number of members and time become in a year. The result shows that in both sectors constructing a new house minimize the number of time people become in suffering in illness 4.30 to 2.50 and also from number of members become ill in a specific year 2019 from 3.60 to 2.1 . The table 7 represents also the difference between the program and non program household health status in terms of frequency of the number of times and houses all members becoming ill in the year. A significant statistical difference has been observed and confirmed by $\mathrm{t}$ test. This study finds a significant difference between program and non program households in terms of the number of times and numbers become sick in a year. No-program household members are getting more than program household and also the numbers of members are suffering from illness more and non-programmed than in the program. Therefore, these significant results also indicate that the Grihayan Tohobil project helps to ensure the SDG3 through improving the health condition of the program beneficiary households.

Table 7. Health Condition of the Respondent Households.

\begin{tabular}{llllll}
\hline \multirow{2}{*}{ Topic } & Before & After & & & \\
\cline { 2 - 6 } & Program & Program & Non-program & t-value & P-value \\
\hline 1. Number of members became sick in a year & 3.60 & 2.10 & 2.20 & -10.3 & 0.00 \\
2. Number of times members became sick in a year & 4.30 & 2.50 & 3.41 & -6.42 & 0.00 \\
\hline
\end{tabular}

Source: Compiled from the Primary Survey

\subsection{Children Education}

Table 8 shows the differences in the indicators of children education between housing fund program beneficiary and non-beneficiaries. The result presents that child education of the program households are in a good position compare to the non-program households. The differences are statistically significant as confirmed by a low p-value. So this result indicates that moving towards sustainable development this project contributing a lot by fulfilling the SDG4.

Table 8. Differences in the Indicators of Children Education between Program Beneficiaries and Non-beneficiaries.

\begin{tabular}{|c|c|c|c|}
\hline Indicators of Children Education & Beneficiary (\%) & Non-Beneficiary $(\%)$ & P-value \\
\hline 1. Children goes school regularly & $0.37(0.01)$ & $0.31(0.02)$ & 0.07 \\
\hline 2. Children gets Private Education (if they needed) & $0.25(0.01)$ & $0.20(0.02)$ & 0.41 \\
\hline 3. Children are encouraged by the family member to continue their study & $0.25(0.01)$ & $0.20(0.02)$ & 0.005 \\
\hline
\end{tabular}

Note: The figure in the parenthesis shows the Standard Error.

Source: Compiled from the Primary Survey.

\subsection{Women Empowerment}

Women empowerments are always consider a social progress indicator in the developing counties like Bangladesh. If any developing country can make their women empowered, then it will be easier for that country to make an inclusive development as well as to fulfill the SDG5. The table 9 presents the differences in the indicators of women empowerment between program beneficiaries and non-beneficiaries households. The result represents that the women who get loan from Grihayan Tohabil they are more empowered than the non-beneficiaries household women, which is also indicating that the project helps to ensure SDG5 by promoting women empowerment. The results are statistically significant as confirmed by a low P-value.

Table 9. Differences in the Indicators of Women Empowerment between Program Beneficiaries and Non-beneficiaries.

\begin{tabular}{|c|c|c|c|}
\hline Indicators of women empowerment & Beneficiary (\%) & Non-Beneficiary (\%) & P-value \\
\hline 1. Women takes decision on children's education & $0.43(0.01)$ & $0.37(0.03)$ & 0.05 \\
\hline 2. Women involves in economic activities actively & $0.30(0.01)$ & $0.27(0.03)$ & 0.41 \\
\hline
\end{tabular}




\begin{tabular}{|c|c|c|c|}
\hline Indicators of women empowerment & Beneficiary (\%) & Non-Beneficiary (\%) & P-value \\
\hline 3. Women select NGOs for loan and attend the NGO meeting & $0.26(0.01)$ & $0.18(0.02)$ & 0.003 \\
\hline 4. Women take decisions about their household's savings and investment issues. & $0.25(0.01)$ & $0.17(0.02)$ & 0.005 \\
\hline
\end{tabular}

Note: The figure in the parenthesis shows the Standard Error.

Source: Compiled from the Primary Survey

\subsection{Clean Water and Sanitation}

Table 10 presents the differences in the indicators of clean water and sanitation between housing fund program beneficiary and non-beneficiaries. The result presents that the access of clean drinking water and hygiene sanitary facilities in both case of the program households are in a good position compare to the non-program households. The differences are statistically significant as confirmed by a low p-value. The availability of pure drinking water and sanitation facilities are also helping to ensure the SGD6.

Table 10. Differences in the Indicators of Clean Water and Sanitation between Program Beneficiaries and Non-beneficiaries.

\begin{tabular}{llll}
\hline Indicators of Children Education & Beneficiary (\%) & Non-Beneficiary (\%) & P-value \\
\hline 1. Access of clean drinking water & $0.43(0.01)$ & $0.37(0.03)$ & 0.05 \\
2. Access of hygiene sanitary facilities & $0.32(0.01)$ & $0.27(0.03)$ & 0.15 \\
\hline
\end{tabular}

Note: The figure in the parenthesis shows the Standard Error.

Source: Compiled from the Primary Survey

All of the findings indicate that after having an access of housing fund loan for a house, it is likely to report positive changes in their social status. The study finds that 90 percent of the program beneficiary households have enjoyed a positive change in their social status. The result indicates that per capita income and expenditure among program beneficiary households are higher than non program households. Which prove that program beneficiaries have higher income and it is connected with the SDG1- "End poverty in all its forms everywhere" [14]. The result also finds that a new house makes people more food secure and which help to ensure SDG2-“End hunger, achieve food security and improved nutrition and promote sustainable agriculture" [15]. The results indicate that a new house lowers the number of members becoming sick and this is also related to the SDG3- "Ensure healthy lives and promote wellbeing for all at all" [16]. Therefore, this also helps to ensure sustainable development. A new house gives them enjoying the opportunity to have proper education as well then the non program households so it is also helping to ensure SDG4- "ensure inclusive and equitable quality education and promote lifelong learning opportunities for all" [17]. Women in the program household are more empowered than non beneficiary household, which is helping to achieve the SDG5-"Achieve gender equality and empower all women and girls" [18]. Moreover, from this study it finds that access of a new house also ensures the availability of pure drinking water and sanitation facilities and which is connected to the SGD6- "Ensure availability and sustainable management of water and sanitation for all" [19].

\section{Conclusion}

Bangladesh is a country of natural diversity. There are natural problems like river erosion and floods. Every year many people become homeless as a result of river erosion. For them, housing loans from the Grihayan Tahobil are a blessing. The most attractive aspect of this loan is that it is available at a very low and simple interest rate of only 5.5 percent. So low income and poor people are able to bear the interest of this loan. The main goal of this study is to evaluate how the social economic development issues change because of the government housing loan program (Grihayan Tahobil) in the Bangladesh to help ensure sustainable development goals.

In conclusion, everyone who has taken out a home loan from Grihayan Tahobil has benefited. In particular, the socio-economic development of each family has been ensured. The various socio-economic indicators that have been taken in this study have led to upward and positive changes in the construction of new homes in each of the cases. Those who have not benefited from this project are lagging behind in every aspect. It is obvious that the housing loan of the housing fund has been helping to change people's lives as well as enhance people's position in the society. In addition, this project significantly contributed to the fulfillment of some important sustainable development goals. However, as there are a lot of homeless people in Bangladesh now, the scope of this project needs to be further expanded so that the poorest people of every division can take advantage of this project and make progress in their social life.

\section{References}

[1] A. Hasnat, M. Kabir, "Development and Human Rights: Litigating the Right to Adequate Housing" Asia Pacific Journal on Human Rights and the Law vol. 1, pp. 97-119, 2002.

[2] World Bank, "Expanding housing finance to the underserved in south Asia: Market review \& forward agenda," Washington, DC, 2010.

[3] Bangladesh Economic Review, Ministry of Finance, Government of the People's Republic of Bangladesh, 2018. 
[4] M. Kamal and Kamruzzaman, "Housing Finance Institutions in Bangladesh-A Comparative Study on BHBFC and DBH," Journal of Business and Economics, vol. 9, No. 1, pp. 27-4, June 2015.

[5] Grihayan Tahobil, www.gtbb.gov.bd. 2019.

[6] J. Gupta \& C. Vegelin "Sustainable development goals and inclusive development", International Environmental Agreements: Politics, Law and Economics, vol. 16, pp. 433448, 2006.

[7] S. Islam and T. Chowdhury, Towards Sustainable Development: Relationship between Human Development Index and Gross Domestic Product Per Capita in Bangladesh. The International Journal of Humanities \& Social Studies, Vol. 6, Issue. 6, pp. 319-325, 2018.

[8] Nadler, Michael, "Evaluating Private Housing Finance Systems", Paper presented at ENHR Conference 2006, Ljubljana.

[9] H. Smit and C. Marja, "Housing Finance in Bangladesh Improving Access to Housing Finance by Middle and Lower Income Groups", Prepared for Ministry of Local Government, Rural Development and Co-operatives, GOB and UNDP/UNCHS (Habitat), 1998.

[10] Karim R., Islam S. Kazi,"Small Scale Private Real Estate Business- Challenges to the sustainable urbanization: A case study of Khulna City", Urban and Rural Planning Discipline, Khulna University, 2010.

[11] UNDP, 2019.

https://www.bd.undp.org/content/bangladesh/en/home/pressce nter/pressreleases/2019/04/07/housing-solutions-for-theurban-poor-in-bangladesh.html
[12] M. Rahman, "PARTICIPATION BY THE NGOS IN HOUSING FOR THE URBAN POOR IN BANGLADESH" BRAC University Journal, vol. II, no. 1, pp. 43-55, 2005.

[13] H. Bhuyan, A. Mondal, Z. Iqbal and M. Ahmed "An Evaluation of the Activities of Grihayan Tahobil (Housing Fund)" Bangladesh Institute of Development Studies (BIDS), 2018.

[14] "Goal 1: No poverty". UNDP, 2015. https://www.undp.org/content/undp/en/home/sustainabledevelopment-goals/goal-1-no-poverty.html Retrieved 28 September, 2019.

[15] "Goal 2: Zero hunger." UNDP, 2015. https://www.undp.org/content/undp/en/home/sustainabledevelopment-goals/goal-2-zero-hunger.html Retrieved 13 September 2019.

[16] “Goal 3: Good health and well-being." UNDP, 2015. https://www.undp.org/content/undp/en/home/sustainabledevelopment-goals/goal-3-good-health-and-well-being.html Retrieved 13 September 2019.

[17] "Goal 4: Quality education". UNDP, 2015. https://www.undp.org/content/undp/en/home/sustainabledevelopment-goals/goal-4-quality-education.html Retrieved 13 September 2019.

[18] "Goal 5: Gender equality". United Nation, 2015. https://www.un.org/sustainabledevelopment/gender-equality/ Retrieved 13 September 2019.

[19] "Goal 6: Clean water and sanitation." UNDP, 2015. https://www.undp.org/content/undp/en/home/sustainabledevelopment-goals/goal-6-clean-water-and-sanitation.html Retrieved 28 September, 2019. 